breath and wheezing. Indeed, it could have been an entirely coincidental series of events that led to the identification and removal of the pacing wire. The significance of this event is in the fact that this wire was found in the right ventricle and pulmonary artery after its placement in the epicardium after coronary artery bypass grafting 24 years previously.

Several case reports have been published pertaining to complications from retained epicardial wire migration. Korompai and colleagues ${ }^{3}$ first reported a case of migrated temporary pacing wire found in the peritoneal cavity in 1987, thought to be retained after cardiac surgery that had been performed 6 years previously. Three years after surgery, Meier and colleagues ${ }^{4}$ reported a case of ventricular tachycardia and cardiac arrest associated with erosion of an epicardial pacing wire through the right atrium. Juchem and colleagues ${ }^{5}$ reported a patient who had undergone mitral valve replacement 2 years previously; aortic and mitral prosthetic valve endocarditis developed secondary to infected pacing wire coursing from the aortic bulb to the right carotid artery.

\section{CONCLUSIONS}

Migration is a well-established albeit rare complication of retained temporary pacing wires, with a variety of clinical effects. The exact mechanism as to how the wire dislodged into the heart is unknown, but it may be a result of constant movement of the heart and diaphragm. We describe the most remote complication of retained pacer wires to date, diagnosed 24 years from placement. The retention of cardiac pacing wires should be communicated to all physicians responsible for the patient's care because it could lead to issues many decades after surgery.

\section{References}

1. Reade MC. Temporary epicardial pacing after cardiac surgery: a practical review. Anaesthesia. 2007;62:264-71.

2. Del Nido P, Goldman BS. Temporary epicardial pacing after open heart surgery: complications and prevention. J Card Surg. 1989;4:99-103.

3. Korompai FL, Hayward RH, Knight WL. Migration of temporary epicardial pacer wire fragment retained after a cardiac operation. J Thorac Cardiovasc Surg. 1987; 94:446-7.

4. Meier DJ, Tamirisa KP, Eitzman DT. Ventricular tachycardia associated with transmyocardial migration of an epicardial pacing wire. Ann Thorac Surg. 2004; 77:1077-9.

5. Juchem G, Golczyk K, Kopf C, Reichart B, Lamm P. Europace. 2008;10:1348-9.

\title{
A new era: Use of an intracorporeal systemic ventricular assist device to support a patient with a failing Fontan circulation
}

\author{
David L. S. Morales, MD, Iki Adachi, MD, Jeffrey S. Heinle, MD, and Charles D. Fraser, Jr, MD, Houston, Tex
}

Worldwide experience with ventricular assist device (VAD) support in patients with univentricular physiology has been very limited. In particular, the use of a long-term continuous-flow implantable VAD has never been described. We report the successful application of an intracorporeal systemic ventricular assist device (SVAD), the HeartMate II (Thoratec Corporation, Pleasanton, Calif), in an adolescent with a failing Fontan circulation and protein-losing enteropathy (PLE).

\section{CLINICAL SUMMARY}

The patient is a 15-year-old boy (body surface area, $1.5 \mathrm{~m}^{2}$ ) with double-outlet right ventricle, mitral atresia,

\footnotetext{
From the Congenital Heart Surgery Division, Texas Children's Hospital, Michael E. DeBakey Department of Surgery, Baylor College of Medicine, Houston, Tex. Disclosures: Authors have nothing to disclose with regard to commercial support. Received for publication Dec 17, 2010; revisions received April 18, 2011; accepted for publication May 23, 2011; available ahead of print July 15, 2011.

Address for reprints: David L. S. Morales, MD, Division of Congenital Heart Surgery,

Texas Children's Hospital, 6621 Fannin St, WT19345H, Houston, TX 77030

(E-mail: dlmorale@texaschildrens.org).

J Thorac Cardiovasc Surg 2011;142:e138-40

$0022-5223 / \$ 36.00$

Copyright (c) 2011 by The American Association for Thoracic Surgery doi:10.1016/j.jtcvs.2011.05.018
}

and a systemic right ventricle. He underwent staged palliation culminating in a fenestrated lateral Fontan operation at 3 years old. Although he did well for many years, his condition began to deteriorate with increasing dyspnea on exertion, peripheral pitting edema, and hepatomegaly with ascites. PLE was diagnosed (serum albumin, $2.6 \mathrm{~g} / \mathrm{dL}$; prealbumin, $9.7 \mathrm{mg} / \mathrm{dL}$ ). Echocardiogram revealed severely depressed systolic ventricular function with significant tricuspid regurgitation. In preparation for cardiac transplantation, a cardiac catheterization was performed. After induction of positive-pressure ventilation, he had several periods of cardiac arrest necessitating resuscitation. The abbreviated catheterization demonstrated a severely elevated Fontan pressure of $30 \mathrm{~mm} \mathrm{Hg}$, a pulmonary vascular resistance of 1.9 Wood units, normal caliber pulmonary arteries, and a wedge pressure of $22 \mathrm{~mm} \mathrm{Hg}$. Because his circulatory failure was primarily the result of systemic ventricular dysfunction and his condition was hemodynamically unstable, he underwent urgent VAD placement.

Because the patient had levocardia with normally related great arteries, a HeartMate II SVAD was implanted in the usual manner (Figure 1) on cardiopulmonary bypass without cardiac arrest. The only atypical aspect was the 


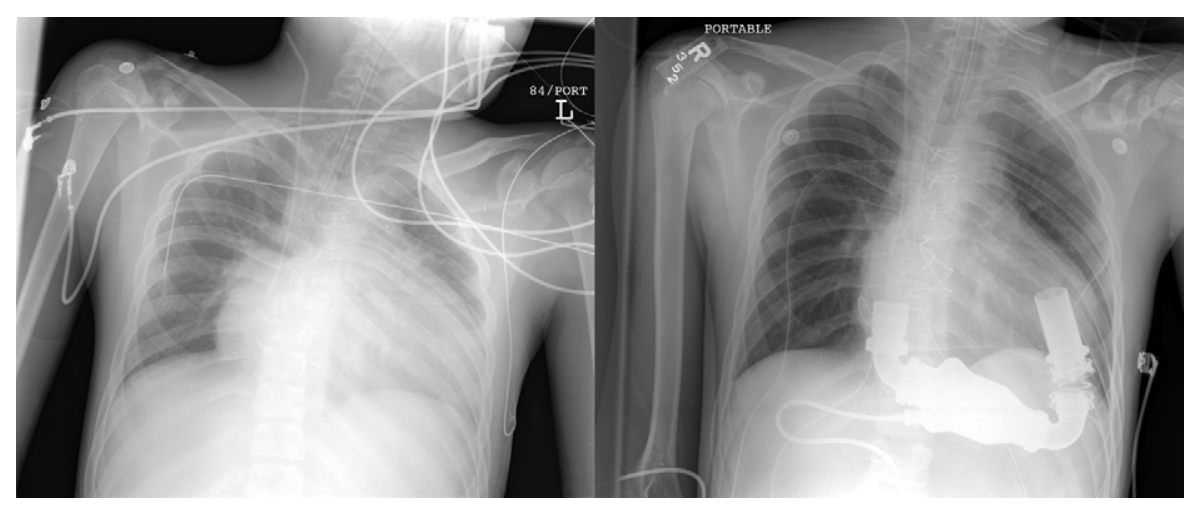

FIGURE 1. Preoperative and postoperative chest x-ray films.

necessity of closing the Fontan fenestration to prevent postoperative cyanosis and aggressively resecting coarse apical right ventricular trabeculations when placing the inflow cannula. After bypass, transesophageal echocardiography demonstrated adequate positioning of the cannulas and good right ventricular decompression with the patient receiving inhaled nitric oxide and nicardipene only.

The patient was in hemodynamically stable condition throughout the postoperative period with a central venous pressure that was $10 \mathrm{~mm} \mathrm{Hg}$ after extubation on postoperative day 7. The HeartMate II SVAD was programmed at higher than normal revolutions per minute to ensure complete decompression of the systemic ventricle because pulmonary blood flow was passive (Table 1). Using aspirin and warfarin sodium (target international normalized ratio of 2.0), there were no thrombotic complications. His exercise tolerance improved significantly, and at 2 months postoperatively he had no heart failure symptoms and the PLE clinically and chemically resolved (albumin, $4.0 \mathrm{~g} / \mathrm{dL}$; prealbumin, 12.0 $\mathrm{mg} / \mathrm{dL}$ ). The patient was discharged home and underwent successful transplant at 72 days of support.

\section{DISCUSSION}

Implantation of a VAD to sustain the Fontan circulation has been reported but mostly in the setting of short-term support using extracorporeal devices or long-term support with paracorporeal devices. ${ }^{1-3}$ Frazier, Gregoric, and Messner ${ }^{1}$ did report the use of a pneumatic HeartMate IP LVAS (Thoratec Corp) in a Fontan patient who while recovering in the hospital received a transplant at 45 days of support. In particular, the use of an implantable VAD in anticipation of longterm support and discharging the patient home has not been described. The chronic failure of a Fontan circulation is multifactorial and is not always primarily a systemic ventricular problem. ${ }^{4}$ This may explain why successful VAD support of the failing Fontan circulation has been inconsistent. Therefore, careful consideration should be given to assess whether systemic ventricular failure is the main cause of the failing

TABLE 1. Hemodynamic and device parameters

\begin{tabular}{|c|c|c|c|c|c|}
\hline & $\begin{array}{c}\text { One day } \\
\text { before operation }\end{array}$ & $\begin{array}{c}\text { One day } \\
\text { after operation }\end{array}$ & $\begin{array}{c}\text { One day } \\
\text { before extubation }\end{array}$ & $\begin{array}{c}\text { One day } \\
\text { after extubation }\end{array}$ & $\begin{array}{c}\text { One day } \\
\text { before discharge }\end{array}$ \\
\hline \multicolumn{6}{|l|}{ Device parameters } \\
\hline Flow (L/min) & - & 5.2 & 5.9 & 6.3 & 6.0 \\
\hline Speed (rpm) & - & 9200 & 9400 & 9400 & 9400 \\
\hline Pump power $(\mathrm{W})$ & - & 5.4 & 5.8 & 6.4 & 7.1 \\
\hline Pulsatile index & - & 3.6 & 3.7 & 4.2 & 4.1 \\
\hline \multicolumn{6}{|l|}{ Hemodynamic parameters } \\
\hline Inotropes/vasodilators & $\begin{array}{l}\text { Epinephrine } 0.1 \\
\mu \mathrm{g} \cdot \mathrm{kg}^{-1} \cdot \mathrm{min}^{-1}, \\
\mathrm{CaCl} 10 \mathrm{mg} \cdot \mathrm{kg}^{-1} \cdot \mathrm{h}, \\
\text { vasopressin } 0.2 \\
\text { units } \cdot \mathrm{kg}^{-1} \cdot \mathrm{h}\end{array}$ & $\begin{array}{r}\text { Nicardipine } \\
1.5 \mathrm{mg} / \mathrm{h}\end{array}$ & $\begin{array}{r}\text { Nicardipine } \\
1.0 \mathrm{mg} / \mathrm{h}\end{array}$ & - & - \\
\hline Respiratory support & Intubated, $\mathrm{FIO}_{2} 1.0$ & $\begin{array}{l}\text { Intubated, } \\
\mathrm{FiO}_{2} 0.4\end{array}$ & $\begin{array}{r}\text { Intubated, } \\
\mathrm{FIO}_{2} 0.4\end{array}$ & $\begin{array}{l}\text { Nasal cannula, } \\
\mathrm{FIO}_{2} 1.0\end{array}$ & Room air \\
\hline Arterial blood pressure $(\mathrm{mm} \mathrm{Hg})$ & $98 / 58(72)$ & (75) & (72) & (84) & (79) \\
\hline Central venous pressure $(\mathrm{mm} \mathrm{Hg})$ & 30 & 15 & 15 & 11 & - \\
\hline Atrial pressure (mm Hg) & $(22)^{*}$ & $(8)^{*}$ & - & - & - \\
\hline Oxygen saturation $(\%)$ & 85 & 93 & 95 & 95 & 92 \\
\hline
\end{tabular}

$\mathrm{Fio}_{2}$, Forced expiratory volume in 1 second. *Estimated with a left pulmonary wedge pressure. 
circulation. If it is, then an SVAD should improve the overall circulation. However, if the left ventricular end-diastolic pressure is not high, then an SVAD is unlikely to improve hemodynamics. If the pulmonary circulation is primarily responsible for hemodynamic deterioration, then insertion of a VAD at a subpulmonary position is an option. ${ }^{2}$ Much animal and computer modeling has been done to study the possibility of mechanically augmenting pulmonary blood flow in the Fontan baffle. ${ }^{5}$

The lack of a subpulmonary ventricle in the Fontan physiology may result in suboptimal filling of an SVAD. Therefore, we believe that it is important to ensure almost complete systemic ventricular decompression by setting the HeartMate II SVAD at higher revolutions per minute to encourage passive flow into the pulmonary arteries. Also, with a single ventricle, unlike in a biventricular heart, there is little concern, even at high revolutions per minute, of jeopardizing output of the pulmonary ventricle by shifting of the intraventricular septum. With these settings, central venous pressure decreased significantly with adequate systemic blood pressure (Table 1), yielding reasonable end-organ perfusion pressure, which presumably contributed to the improvement in his PLE.

This is the first report of successfully discharging home a patient who has a failing Fontan circulation with an implantable VAD. Given the increasing cohort of adults and children with failing Fontan circulations, this case represents a significant evolution in therapy for single ventricle patients who will increasingly be receiving SVADs not only for support to transplant but also perhaps to destination.

\section{References}

1. Frazier OH, Gregoric ID, Messner GN. Total circulatory support with an LVAD in an adolescent with a previous Fontan procedure. Tex Heart Inst J. 2005;32:402-4.

2. Prêtre R, Häussler A, Bettex D, Genoni M. Right-sided univentricular cardiac assistance in a failing Fontan circulation. Ann Thorac Surg. 2008;86:1018-20.

3. Nathan M, Baird C, Fynn-Thompson F, Almond C, Thiagarajan R, Laussen P, et al. Successful implantation of a Berlin heart biventricular assist device in a failing single ventricle. J Thorac Cardiovasc Surg. 2006;131:1407-8.

4. Morales DLS, Fraser CD. Surgical strategy for the failing systemic ventricle. In: Chang AC, Towbin JA, eds. Heart failure in children and young adults. Philadelphia: Elsevier; 2006. p. 591-606.

5. Lacour-Gayet FG, Lanning CJ, Stoica S, Wang R, Rech BA, Goldberg S, et al. An artificial right ventricle for failing Fontan: in vitro and computational study. Ann Thorac Surg. 2009;88:170-6.

\title{
The use of the HeartWare HVAD for long-term right ventricular support after implantation of the HeartMate II device
}

\author{
John M. Stulak, MD, Kevin E. Griffith, John M. Nicklas, MD, and Francis D. Pagani, MD, PhD, \\ Ann Arbor, Mich
}

Biventricular support is required in approximately $6 \%$ to $30 \%$ of patients undergoing implantation of left ventricular assist devices (LVADs). ${ }^{1}$ Although the routine application of a reliable, long-term implantable right ventricular assist device (RVAD) remains elusive, use of the HeartWare HVAD (HeartWare International, Inc, Framingham, Mass) and Jarvik 2000 (Jarvik Heart, Inc, New York, NY) for long-term totally implantable biventricular support has been reported. ${ }^{2,3}$ Although the only reports in existence detail the use of 2 HeartWare HVADs for

\footnotetext{
From the Section of Cardiac Surgery, University of Michigan Health System, Ann Arbor, Mich.

Disclosures: Authors have nothing to disclose with regard to commercial support. HeartWare HVAD is manufactured by HeartWare International, Inc, Framingham, Mass.

HeartMate II is manufactured by Thoratec Corporation, Pleasanton, Calif.

Received for publication Feb 25, 2011; revisions received March 18, 2011; accepted for publication April 11, 2011; available ahead of print May 18, 2011.

Address for reprints: Francis D. Pagani, MD, PhD, 5144 Cardiovascular Center, 1500 East Medical Center Dr, Ann Arbor, MI 48109 (E-mail: jstulak@yahoo.com).

J Thorac Cardiovasc Surg 2011;142:e140-2

0022-5223/\$36.00

Copyright (c) 2011 by The American Association for Thoracic Surgery doi:10.1016/j.jtcvs.2011.04.012
}

biventricular support, we report the use of this device for right ventricular support after implantation of a HeartMate II LVAD (Thoratec Corporation, Pleasanton, Calif).

\section{CLINICAL SUMMARY}

A 59-year-old African American woman with nonischemic cardiomyopathy and congestive heart failure was seen with acute, decompensated heart failure and rapidly deteriorating condition. After evaluation, the patient underwent emergency HeartMate II and CentriMag RVAD (Thoratec) implantation for biventricular failure. Postoperatively, the patient had several failed attempts at RVAD weaning and was subsequently listed status $1 \mathrm{~A}$ for heart transplant. After transplant workup, numerous antibodies with a high panelreactive antibody titer were noted, and the patient underwent several rounds of plasmapheresis, intravenous immune globulin, and bortezomib (Velcade). Despite these interventions, transplant was essentially excluded as a result of significant persistent allosensitization. An appeal was subsequently made for compassionate use of the HeartWare 